\title{
PENGARUH KONFLIK PEKERJAAN KELUARGA TERHADAP KEINGINAN UNTUK KELUAR MELALUI MEDIASI KEPUASAN KERJA
}

\author{
I Putu Adhi Mardhika ${ }^{1}$ \\ Anak Agung Sagung Kartika Dewi ${ }^{2}$
}

${ }^{1,2}$ Fakultas Ekonomi dan Bisnis Universitas Udayana (Unud), Bali, Indonesia E-mail:adhimardhika666@gmail.com

\begin{abstract}
ABSTRAK
Tujuan penelitian yang hendak dicapai adalah untuk menganalisis pengaruh konflik pekerjaan keluarga terhadap kepuasan kerja , pengaruh konflik pekerjaan keluarga terhadap keinginan untuk keluar, pengaruh kepuasan kerja terhadap keinginan untuk keluar, serta pengaruh konflik pekerjaan keluarga terhadap keinginan untuk keluar melalui mediasi kepuasan kerja. Sampel dalam penelitian ini berjumlah 49 responden. Analisis menggunakan analisis jalur menyatakan bahwa konflik pekerjaan keluarga berpengaruh negatif terhadap kepuasan kerja, konflik pekerjaan keluarga berpengaruh positif terhadap keinginan untuk keluar, kepuasan kerja berpengaruh negatif terhadap keinginan untuk keluar, serta kepuasan kerja memediasi konflik pekerjaan keluarga terhadap keinginan untuk keluar. Penyebab keinginan untuk keluar karena adanya tekanan dari atasan. Saran yang dapat diberikan adalah manajemen departemen personalia The Jayakarta Hotel Bali hendaknya selalu memperhatikan faktor-faktor yang menyebabkan konflik pekerjaan keluarga karyawan di tempat kerja agar tidak menimbulkan kesulitan pemenuhan peran dalam keluarga dan kesulitan pemenuhan peran dalam pekerjaan.
\end{abstract}

Kata kunci: konflik pekerjaan keluarga, keinginan untuk keluar, kepuasan kerja

\section{ABSTRACT}

The purpose of the research to be achieved is to analyze the effect of family work conflict on job satisfaction, the effect of family work conflict on the desire to leave, the effect of job satisfaction on the desire to leave, and the influence of family work conflict on the desire to leave through mediating job satisfaction. Analysis using path analysis states that family work conflict has a negative effect on job satisfaction, family work conflict has a positive effect on the desire to leave, job satisfaction negatively influences the desire to leave, and job satisfaction mediates family work conflicts against the desire to leave. Suggestions that can be given are the management of the personnel department of The Jayakarta Hotel Bali should always pay attention to the factors that cause work conflicts of the employee's family in the workplace so as not to cause difficulties in fulfilling roles in the family and difficulties in fulfilling roles in the work.

Keywords: family work conflict, desire to quit, job satisfaction 


\section{PENDAHULUAN}

Di era seperti sekarang ini kemajuan perusahaan merupakan tujuan utama yang diinginkan setiap perusahaan, dibalik dari kemajuan yang diraih pasti terdapat Sumber Daya Manusia (SDM) yang handal dalam menggerakan perusahaan tersebut. Selain dari modal yang diperlukan untuk mendirikaan sebuah perusahaan,karyawan juga merupakan salah satu unsur penting yang harus dimiliki oleh perusahaan. Tanpa ada karyawan yang memilki loyalitas yang baik terhadap perusahaan maka perusahaan tidak akan bisa mencapai titik keberhasilannya secara maksimal. Oleh karena itu perusahaan harus mampu memperhatikan setiap kondisi karyawan, sehingga dapat membuat karyawan merasa tenang dalam bekerja tanpa adanya rasa tertekan dalam melakukan pekerjaannya yang nantinya akan memberikan hasil yang maksimal terhadap perusahaan. Pada suatu perusahaan, Manajemen Sumber Daya Manusia (MSDM) memiliki peranan yang penting dalam mengelola para karyawan. Pengelolaan dilakukan agar setiap karyawan dapat bekerja sesuai dengan keahliaannya dan sesuai dengan job description yang terarah.MSDMsangat penting dilakukan untuk dapat mempertahankan karyawan yang berpotensi tinggi terhadap perusahaan agar karyawan tersebut tidak memilki keinginan untuk berpindah.

Jika dalam suatu perusahaan memiliki keinginan untuk keluaryang tinggi maka itu dapat membuat permasalahan besar yang berdampak pada aktifitas dan produktifitas perusahaan. Perusahaan akan mengalami kepanikan jika mengetahui karyawannya memiliki keinginan untuk keluar dari perusahaan, apalagi karyawan tersebut dapat digolongkan sebagai karyawan yang berdedikasi tinggi terhadap 
perusahaan dan memiliki kualitas kerja yang baik. Maka dapat dipastikan kerugian yang akan ditanggung oleh perusahaan jika karyawan memiliki keinginan untuk keluar dari perusahaan tersebut. Hal utama yang akan menjadi masalah yang dihadapi perusahaan adalah mencari karyawan yang baru yang perlu mengeluarkan dana untuk melakukan proses rekrutmen agar dapat mendapat karyawan yang memiliki loyalitas tinggi terhadap perusahaan yang dimana sangat banyak memakan waktu dan dana dalam melakukan rekrutmen.

Tett dan Meyer (1993) mengemukakan bahwa keinginan untuk keluar tersebut merupakan keinginan individu yang dilakukan secara sadar serta disengaja untuk keluar dari perusahaan dimana tempat karyawan tersebut bekerja. Keinginan untuk keluarmerupakan tujuan akhir yang akan dipilih oleh karyawan jika merasa dirinya tidak puas pada pekerjaan dan susah beradaptasi dengan lingkungan kerjanya. Keinginan untuk keluar bisa terjadi karena karyawan memiliki peran ganda yaitu dalam melakukan pekerjaannya dan dalam keluarga yang disebut dengan konflik peran keluarga.

Konflik pekerjaan keluargaadalah konflik yang terjadi pada individu akibat menanggung peran ganda baik dalam pekerjaan maupun keluarga (Greenhaus dan Beutell : 1985). Masalah yang biasanya memicu terjadinya konflik pekerjaan keluarga yaitu jam kerja dan beban kerja yang dimiliki oleh seorang karyawan terlalu padat, seluruh perhatian dan pikiran hanya tercurahkan pada satu peran saja. Pada dasarnya bahwa konflik peran keluarga dapat terjadi pada pria dan wanita, namun beberapa penelitian menunjukan bahwa wanita lebih besar memiliki intensitas dalam terjadinya konflik peran keluarga (Apperson et 
al.,2002). Tingkat konflik ini akan semakin meningkat jika karyawan yang bekerja disebuah perusahaan bekerja secara formal otomatis itu akan membuat mereka terikat oleh aturan organisasi yang meliputi jam kerja, penugasan, serta target dalam meyelesaikan suatu pekeerjaan.Konflik pekerjaan keluarga ini akan lebih dirasakan lagi jika karyawan sudah menikah karena peran tradisional yang sampai saat ini tidak dapat dihindari adalah mengurus rumah tangga (Widyaningrum, 2013).

Pembagian peran antara keluarga dan pekerjaan menjadisebuah problematika yang dihadapi oleh karyawan, pada nyatanya banyak karyawan yang tidak cukup mampu mengatasi permasalahan ini meskipun sudah memiliki cara-cara untuk mengimbangi antara keluarga dan pekeerjaan. Primastuti (2000) mengemukakan bahwa kebanyakan peranan ganda ini dilakukan untuk mendapatkan penghasilan dan kepuasan kerja, sehingga dalam menjalani kedua peranan ini akan menimbulkan adanya koflik. Kondisi ini akan menimbulkan perasaan bersalah saat karyawan tersebut bekerja. Perasaan bersalah ini ditambah dengan tuntutan dari dua sisi yakni tuntutan di dalam keluarga dan juga tuntutan di dalam pekerjaan akan memicu terjadinyakonflik peran keluarga, yang pada akhirnya akan berujung stress (Rini, 2002). Perasaan tidak nyaman yang dirasakan seiring dengan permasalahan yang dihadapi tersebut nantinya akan dapat menyebabkan karyawan mengalami keinginan untuk keluar dari tempatnya bekerja.

Agar tidak mengarah terhadap keinginan untuk keluar dari perusahaan,makakepuasan kerja dari setiap karyawan harus sangat benar-benar 
diperhatikan. Kepuasan dalam kehidupan keluarga sangat berkontribusi terhadap kehidupan pekerjaan, maka dengan demikian keduanya saling mempengaruhi (Amstadet al., 2011). Kepuasan kerja karyawan memiliki pengaruh yang sangat besar untuk dapat mempertahankan karyawan dan perusahaan, yang nantinya karyawan yang memiliki kepuasan terhadap pekerjaannya maka produktifitas dari perusahaan akan meningkat.

Kepuasan kerja yang dirasakan dapat memacu karyawan tersebut untuk melakukan pekerjaan dengan lebih baik serta membuat karyawan untuk tetap bertahan di perusahaan, sebaliknya jika kepuasan kerja tidak didapatkan oleh karyawan maka perusahaan akan menanggung kerugian yang pada akhirnya akan menyebabkan karyawan mengarah pada keinginan untuk keluar mencari pekerjaan yang lebih baik.Menurut Laksmi (2012) mengemukakan bahwa jika karyawan merasa tidak puas maka karyawan akan melakukan penurunan kinerja dalam melakukan pekerjaan.

The Jayakarta Hotel Bali adalah badan usaha yang bergerak dalam bidang pariwisata. The Jayakarta Bali memiliki tempat yang sangat strategis dalam memilih lokasi dan memiliki akses yang cepat menuju pantai,tempat perbelanjaan,hiburan malam,dan sangat mudah dalam mencari akses transportasi umum. The Jayakarta Bali yang merupakan hotel berbintang 4 yang mengkombinasikan suasana tradisional dan modern serta memiliki harga sewa yang cukup terjangkau. The Jayakarta Bali ini termasuk hotel yang memiliki service yang baik, maka dari itu karyawan yang bekerja di The Jayakarta Bali dituntut untuk memiliki potensial dan loyalitas yang tinggi terhadap pekerjaannya. 
Oleh karena itu manajemen hotel perlu memperhatikan sumber daya manusia agar tetap dapat bertahan dalam mengelola perusahaan.

Berdasarkan hasil wawancara dengan pihak Human Resource Departement Hotel The Jayakarta Bali bahwa penyebab terjadinya keinginan untuk keluar pada karyawan disebabkan karena terdapat penurunan kepuasan kerja yang ditunjukan dengan gejala-gejala yang terlihat seperti menurunnya kegairahan karyawan dalam melaksanakan pekerjaan, rendahnya inisiatif karyawan, seringnya karyawan datang tidak tepat waktu yang menandakan karyawan tersebut tidak disiplin, dan kurang terjalinnya kerjasama antar karyawan.

Penyebab lainnya kemangkiran yang dilakukan karyawan adalah adanya tuntutan peran yang berat dalam pekerjaan yang dimana karyawan merasa adanya tekanan atas beban pekerjaan. Ditunjukkan dengan banyaknya pekerjaan yang harus dikerjakan sesuai dengan waktu yang ditentukan (deadline). Dalam banyaknya pekerjaan yang diberikan dengan waktu yang bisa terbilang singkat bagian yang paling merasakan tekanan berlebih adalah bagian room division. Pada bagian room division ini memang benar mengalami tekanan yang cukup berat atas waktu karena pada divisi ini mereka melakukan komunikasi langsung terhadap tamu yang beragam dengan situasi kerja yang tidak menentu. Setelah saya melakukan pra riset terhadap beberapa karyawan yang bekerja pada bagian ini memang benar adanya tuntutan yang berat atas pekerjaannya dan ada kemungkinan mereka bisa meninggalkan pekerjaan jika bisa mendapat tempat pekerjaan yang lebih baik. Tekanan terhadap waktu juga dialami oleh beberapa karyawan yang memiliki kesulitan untuk menukar shift pada karyawan lain bila 
memang karyawan tersebut memiliki kepentingan dikeluarga ataupun diluar lingkungan hotel. Banyaknya tekanan yang dihadapi oleh karyawan baik itu waktu, tenaga, pekerjaan yang berlebih secara langsung akan mempengaruhi peranan karyawan tersebut di dalam keluarganya. Fenomena yang disebabkan oleh konflik pekerjaan keluarga disini adalah dimana karyawan kurang bisa mengimbangi pekerjaan di hotel dan pekerjaannya dirumah untuk mengurus rumah tangga yang dapat menyebabkan terjadinya masalah seperti tidak fokus dalam melakukan tugas yang diberikan oleh kantor yang nantinya karyawan tersebut bisa memiliki pikiran untuk mencari pekerjaan lain yang menurutnya bisa membuat dirinya lebih baik dalam memenuhi antara pekerjaan mengurus rumah tangga dan pekerjaan di tempatnya bekerja.

Beberapa penelitian yang menguji pengaruh konflik pekerjaan keluarga terhadap keinginan untuk keluar, yang di antaranya adalah penelitian yang dilakukan oleh (Raza-ullah et al., 2014) kepada 355 responden dari empat Universitas Sektor Publik di Islamabad yang menemukan hasil bahwa terdapat hubungan positif signifikan antara konflik pekerjaan keluarga dan keinginan untuk keluar.

Waspodo dkk. (2013) melakukan penelitian pada PT. Unitex di Bogor yang menemukan bahwa kepuasan kerja memiliki pengaruh negatif signifikan terhadap keinginan untuk keluar karyawan. Yuliana dan Yuniasanti (2013) menemukan bahwa terdapat hubungan negatif antara konflik pekerjaan keluarga dengan kepuasan kerja pada polisi wanita di Polres Kulon Progo. 
Susanto (2010) menjelaskan konflik pekerjaan keluarga dalam penelitiannya sebagai bentuk peran yang dituntut dalam pekerjaan dan keluarga akan saling mempengaruhi, mempunyai dua dimensi: pertama yaitu pemenuhan peran dalam pekerjaan dapat menimbulkan kesulitan pemenuhan peran dalam keluarga dan yang kedua yaitu pemenuhan peran dalam keluarga dapat menimbulkan kesulitan pemenuhan peran dalam pekerjaan. Ghayyur dan Jamal (2012) mengungkapkan konflik pekerjaan keluarga adalah jenis resistensi tekanan peran yang muncul dari tempar kerja dan mempengaruhi lingkup keluarga dan saling bertentangan.

Kepuasan kerja mencerminkan perasaan seseorang terhadap pekerjaannya, ini nampak dalam sikap positif karyawan terhadap pekerjaan dan segala sesuatu yang dihadapi di lingkungan kerjanya. Locke (dalam Turkyimaz et al., 2011) mengatakan bahwa kepuasan kerja merupakan suatu perasaan positif yang timbul dari pegawai sebagai hasil dari pengakuan terhadap pekerjaannya atau pengalamannya dalam bekerja. Menurut Rini dkk. (2013) kepuasan kerja adalah suatu ungkapan perasaan menyenangkan dari hasil persepsi individu dalam rangka menyelesaikan tugas atau memenuhi kebutuhannya dalam memperoleh nilai-nilai kerja yang penting bagi dirinya. Kepuasan dapat menggambarkan perasaan positif dan negatif pegawai dari persepsi terhadap pekerjaan yang dihadapinya, seperti perasaan untuk berprestasi dan meraih kesuksesan dalam pekerjaan, mengimplementasikan kepuasan yang tinggi terhadap pegawai yang merasa senang dan nyaman dengan kondisi lingkungan organisasi dan mendapatkan penghargaan dari jerih payah hasil kerjanya (Aziri, 2011). 
Penelitian sebelumnya dibuktikan antara keluargadan tugasmengidentifikasi bahwa pekerjaan yang tidak bisa menyeimbangkan antara keutuhan pekerjaan dengan tanggung jawab keluarga dan rumah tangga serta mengalami benturan terhadap hal tersebut maka akan menghasilkan penurunan kepuasan kerja (Netermeyer et al., 2004). Menurut Latifah (2008) kepuasan kerja merupakan masalah yang secara umum banyak dihasilkan dari pengujian dalam konflik pekerjaan keluarga yang menimbulkan ketidakpuasan dalam pekerjaan. Hal yang sama juga dikemukakan oleh Rantika dan Sunjoyo (2011) mengatakan bahwa konflik antara tanggung jawab pekerjaan dan keluarga mengakibatkan rendahnya kepuasan kerja, meningkatnya absensi, menurunkan motivasi karyawan dan dalam jangka waktu kedepan akan dapat menyebabkan keinginan keluarkaryawan yang meningkat. Penelitian lain yang dilakukan oleh Laksmi (2012) pada PT.X dengan sampel yang berjumlah 54 orang menemukan bahwa hubungan konflik pekerjaan keluarga dengan kepuasan kerja memiliki hubungan yang negatif, yang artinya bahwa semakin tinggi tingkat konflik peran keluarga yang dirasakan maka kepuasan kerjanya akan semakin rendah. Selain itu penelitian yang dilakukan oleh Susto (2010) pada hasil studi metaanalisis menunjukan bahwa terdapat hubungan negatif antara konflik pekerjaan keluarga dengan kepuasan kerja, dimana semakin besar konflik pekerjaan keluarga yang dialami oleh karyawan maka akan semakin rendah kepuasan yang dirasakan.

Berdasarkan uraian diatas, hipotesis penelitian yang didapat adalah sebagai berikut:

$\mathrm{H}_{1}$ :Konflik Pekerjaan Keluargaberpengaruh negatif dan signifikan terhadap kepuasan kerja. 
Penelitian sebelumnya dilakukan pada 355 responden dari empat Universitas Sektor Publik di Islamabad yang menemukan hasil bahwa terdapat hubungan positif signifikan antara konflik pekerjaan keluarga dan keinginan untuk keluar (Raza-ullah et al., 2014). Penelitian yang dilakukan oleh (Blomme et al., 2010) dalam penelitiannya menemukan hasil bahwa sejumlah besar karyawan yang berpendidikan tinggi tentang niat untuk meninggalkan organisasi menemukan bahwa konflik pekerjaan keluarga memiliki pengaruh positif terhadap keinginan untuk keluar. Penelitian lain oleh (Nohe dan Sontag, 2014) menguji apakah ada hubungan timbal balik antara konflik pekerjaan keluarga dengan keinginan untuk keluar yang menemukan bahwa keinginan untuk keluar dapat meningkat apabila mendapat pengaruh dari konflik pekerjaan keluarga dalam lima bulan kedepan. Hal yang sama juga dikemukakan oleh Ghayyur dan Jamal (2012) dalam penelitiannya menyatakan bahwa konflik pekerjaan keluarga berpengaruh positif dan signifikan terhadap keinginan untuk keluar. Netmeyer et al. (1996) menemukan bahwa konflik peran keluarga terkait langsung dengan keinginan untuk keluar.

Berdasarkan uraian diatas, hipotesis penelitian yang didapat adalah sebagai berikut:

$\mathrm{H}_{2}$ : Konflik Pekerjaan Keluarga berpengaruh positif dan signifikan terhadap Keinginan Untuk Keluar

Sebagian studi empiris menunjukan bahwa kepuasan kerja berpengaruh negatif terhadap absensi dan keinginan untuk berpindah karyawan (McClean \& andrew, 2000). Kepuasan kerja berpengaruh terhadap keputusan karyawan untuk 
tinggal atau meninggalkan organisasi, jika karyawan tidak puas dengan pekerjaanpekerjaan mereka, karyawan akan meninggalkan organisasi tersebut, begitupun sebaliknya jika karyawan percaya bahwa mereka diperlakukan secara adil dan mendapatkan penghargaan mereka tidak mungkin meninggalkan organisasi (Aydogdu dan Asikgil, 2011). Sebaliknya banyak studi di negara-negara barat secara konsisten menunjukan pengaruh negatif dan signifikan antara kepuasan kerja dan keingian untuk keluar di kalangan karyawan (Salleh et al., 2012). Pengaruh negatif yang dibuktikan oleh penelitian tersebut berupaya menjelaskan bahwa semakin tinggi kepuasan kerja, maka terdapat kecenderungan rendahnya niat keluar dari perusahaan (Andini, 2013). Hal yang sama juga ditemukan oleh Park dan Kim (2009) bahwa kepuasan kerja berhubungan signifikan dan negatif terhadap keinginan untuk keluar. Berdasarkan uraian diatas, hipotesis penelitian yang didapat adalah sebagai berikut:

$\mathrm{H}_{3}$ : Kepuasan Kerja berpengaruh negatif dan signifikan terhadap Keinginan Untuk Keluar

Pengaruh konflik pekerjaan terhadap keinginan keluar kerja karyawan menunjukan kesimpulan mediasi yang bersifat berlawanan. Ini artinya bahwa peningkatan konflik pekerjaan yang dihadapi oleh karyawan ketika bekerja akan berdampak terhadap penurunan kepuasan kerja. Irzani (2014) memperoleh hasil bahwa analisis pengaruh langsung menyimpulkan bahwa kepuasan kerja memediasi secara parsial negatif dengan keinginan keluar karyawan. Berdasarkan uraian diatas, hipotesis penelitian yang didapat adalah sebagai berikut:

$\mathrm{H}_{4}$ : Kepuasan Kerja Memediasi Konflik Pekerjaan Keluarga Terhadap Keinginan Untuk Keluar 


\section{METODE PENELITIAN}

Penelitian ini dilakukan di Hotel The Jayakarta Bali yang beralamat di Jalan Werkudara, Legian, Kuta Bali. Penelitian ini dilakukan padaHotel The Jayakarta Bali karena ditemukan adanya masalah yang terkait dengan keinginan untuk keluar terhadap karyawan.

Populasi dalam penelitian ini adalah seluruh karyawan pada staff room division The Jayakarta Hotel Bali. Jumlah populasi pada penelitian ini adalah 49 karyawan. Sampel yang di pilih dalam penelitian ini menggunakan sampel jenuh yaitu teknik penentuan sampel bila semua anggota populasi digunakan sebagai sampel. Metode penentuan sampel yang dipakai adalah sampel jenuh dimana sampel tersebut adalah seluruh karyawan The Jayakarta Hotel khususnya yang bekerja di bagian room division yang berjumlah 49 orang karyawan.

Penelitian ini menggunakan teknik analisis jalur atau path analysis. Analisis jalur (path analysis) adalah perluasan dari analisis regresi linier berganda, dimana pengembangan disini berupa penerapan variabel mediasi. Variabel mediasi merupakan variabel yang memiliki peran memediasi hubungan antara suatu variabel dengan variabel lainnya. Analisis jalur hanya dapat digunakan apabila telah memenuhi asumsi-asumsi tertentu.

Persamaan Sub-struktural 1

$\mathrm{M}=\beta_{1} \mathrm{X}_{1}+\mathrm{e}_{1}$

Persamaan Sub-struktural 2

$\mathrm{Y}=\beta_{1} \mathrm{X}_{2}+\beta_{1} \mathrm{M}+\mathrm{e}_{2}$ 
Keterangan:

$\mathrm{X} \quad=$ Konflik Pekerjaan Keluarga

$\mathrm{M} \quad=$ Kepuasan Kerja

$\mathrm{Y} \quad=$ Keinginan Keluar

$\beta_{1-} \beta_{2}=$ Koefisien regresi variabel

e $=$ error

Pengujian hipotesis mediasi dapat dilakukan dengan Uji Sobel (Sobel Test).

Uji sobel digunakan untuk menguji kekuatan pengaruh tidak langsung variabel konflik pekerjaan keluarga (X) ke variabel keinginan untuk keluar(Y) melalui variabel kepuasan kerja(M). Pengaruh tidak langsungkonflik pekerjaan keluarga (X) terhadap variabel keinginan untuk keluar (Y) melalui variabel kepuasan kerja (M) dihitung dengan mengalikan koefisien jalur $\mathrm{X}$ terhadap $\mathrm{M}$ (a) dengan koefisien jalur M terhadap Y (b) atau ab. Standard error koefisien a dan b ditulis dengan $S_{a}$ dan $S_{b}$, besarnya standard error tidak langsung (indirect effect) $S_{a b 1}$ dihitung dengan rumus dibawah ini:

$$
\mathrm{Sab}=\sqrt{b^{2} S a^{2}+a^{2} S b^{2}+S a^{2} S b^{2}}
$$

Untuk menguji signifikansi pengaruh tidak langsung, maka dapat dilakukan dengan menghitung $\mathrm{t}$ dari koefisien ab dengan rumus sebagai berikut:

$$
\mathrm{Z}=\frac{a b}{\mathrm{Sab}}
$$

\section{HASIL DAN PEMBAHASAN}

Perhitungan koefisien analisis jalur dilakukan dengan analisis regresi melalui software IBM SPSS Statistics 20.0 memperoleh hasil yang ditunjukkan pada Tabel 1 dan Tabel 2.

Tabel 1.

\section{Hasil Analisis Jalur Persamaan Regresi 1 (Konflik Pekerjaan Keluarga} terhadap Kepuasan Kerja) 


\begin{tabular}{cccc}
\hline Model & R Square & $\begin{array}{c}\text { Standardized Coefficients } \\
\text { Beta }\end{array}$ & Sig. \\
\hline $\begin{array}{c}\text { Konflik Pekerjaan } \\
\text { Keluarga }\end{array}$ & 0,238 & $-0,322$ & 0,024 \\
\hline Sumber: Data diah & 2018 & &
\end{tabular}

Sumber: Data diolah, 2018

Berdasarkan hasil analisis jalur substruktural 1 yang disajikan pada Tabel 1, maka persamaan strukturalnya adalah:

$$
\begin{aligned}
& M=\beta_{1} X+e \\
& M=-0,322 X+e_{1}
\end{aligned}
$$

Berdasarkan hasil analisis jalur substruktural 2 yang disajikan pada Tabel 2, maka persamaan strukturalnya adalah:

$$
\begin{aligned}
& Y=\beta_{2} X+\beta_{3} M+e_{2} \\
& Y=0,437 X-0,441 M+e_{2}
\end{aligned}
$$

Tabel 2.

Hasil Analisis Jalur Persamaan Regresi 2 (Konflik Pekerjaan Keluarga dan Kepuasan Kerja terhadap Keinginan Untuk Keluar)

\begin{tabular}{cccc}
\hline & \multicolumn{3}{c}{ Standardized Coefficients } \\
Model & R Square & Beta & Sig. \\
\hline Konflik Pekerjaan Keluarga & 0,593 & 0,437 & 0,002 \\
Kepuasan Kerja & & $-0,441$ & 0,001 \\
\hline
\end{tabular}

Sumber:Data diolah, 2018

Berdasarkan model substruktural 1 dan substruktural 2, maka perhitungan nilai standar eror adalah sebagai berikut:

$$
\begin{aligned}
& \mathrm{ei}=\sqrt{1-\mathrm{Ri}^{2}} \ldots \ldots \ldots \ldots \ldots \ldots \ldots \ldots \ldots \ldots \ldots \ldots \\
& \mathrm{e}_{1}=\sqrt{1-\mathrm{R}_{1}^{2}}=\sqrt{1-0,238}=0,873 \\
& \mathrm{e}_{2}=\sqrt{1-\mathrm{R}_{2}^{2}}=\sqrt{1-0,593}=0,638
\end{aligned}
$$

Tabel 3.

Hasil Pengujian Nilai Standar Eror

\begin{tabular}{ccc}
\hline Hasil Pengujian & Nilai Standar Eror & Keterangan \\
\hline $\mathrm{e}_{1}$ & 0,873 & Standar eror variabel kepuasan kerja
\end{tabular}




\begin{tabular}{ccc}
$\mathrm{e}_{2}$ & 0,638 & Standar eror variabel keinginan untuk keluar \\
\hline Sumber: Data diolah, 2018 &
\end{tabular}

Berdasarkan perhitungan nilai standar eror, diperoleh hasil $\mathrm{e}_{1}$ atau standar eror variabel kepuasan kerja sebesar 0,873 dan $\mathrm{e}_{2}$ atau standar eror variabel keinginan untuk keluarsebesar 0,638. Perhitungan koefisien determinasi total adalah sebagai berikut:

$$
\begin{aligned}
\mathrm{R}^{2} \mathrm{~m} & =1-\left(\mathrm{e}_{1}\right)^{2}\left(\mathrm{e}_{2}\right)^{2} \ldots \ldots \ldots \ldots \ldots \ldots \ldots \ldots \ldots \ldots \ldots \ldots \ldots \ldots \ldots \ldots \ldots \ldots \ldots \ldots \\
& =1-(0,873)^{2}(0,638)^{2} \\
& =0,690
\end{aligned}
$$

Nilai determinasi total sebesar 0,690 mempunyai arti bahwa sebesar 69\% variasi keinginan untuk keluar dipengaruhi oleh variasi konflik pekerjaan keluargadan kepuasan kerja, sedangkan sisanya sebesar $31 \%$ dipengaruhi oleh faktor lain yang tidak dimasukkan ke dalam model penelitian.

Berdasarkan hasil regresi persaman 2 pada tabel 2diperoleh nilai $\mathrm{F}$ sebesar 7,104 dengan nilai signifikansi 0,002 . Oleh karena nilai signifikansilebih kecil dari $0,05(0,002<0,05)$, maka dapat disimpulkan bahwa $\mathrm{H}_{0}$ ditolak dan $\mathrm{Ha}$ diterima. Dengan demikian, dapat ditarik keputusan bahwa variabel konflik pekerjaan keluarga dan kepuasan kerja berpengaruh secara simultan dan signifikan terhadap keinginan untuk keluar.

Berdasarkan hasil analisis pengaruh konflik pekerjaan keluarga terhadap kepuasan kerja, diperoleh nilai koefisien beta sebesar -0,322 yang berarti adanya arah yang negatif serta nilai signifikansi sebesar 0,024 yang kurang dari 0,05 berarti adanya pengaruh yang signifikan. Hasil ini mengindikasikan bahwa $\mathrm{H}_{0}$ ditolak dan $\mathrm{H}_{1}$ diterima sehinggakonflik pekerjaan keluarga berpengaruh negatif dan signifikan terhadap kepuasan kerja. 
Berdasarkan hasil analisis pengaruh konflik pekerjaan keluarga terhadap keinginan untuk keluar, diperoleh nilai koefisien beta sebesar 0,437 yang berarti adanya arah yang positif serta nilai signifikansi sebesar 0,002 yang kurang dari 0,05 berarti adanya pengaruh yang signifikan. Hasil ini mengindikasikan bahwa $\mathrm{H}_{0}$ ditolak dan $\mathrm{H}_{2}$ diterima sehingga konflik peran keluarga berpengaruh positif dan signifikan terhadap keinginan untuk keluar.

Berdasarkan hasil analisis pengaruh kepuasan kerja terhadap keinginan untuk keluar, diperoleh nilai koefisien beta sebesar -0,441 yang berarti adanya arah yang negatif serta nilai signifikansi sebesar 0,001 yang kurang dari 0,05 berarti adanya pengaruh yang signifikan. Hasil ini mengindikasikan bahwa $\mathrm{H}_{0}$ ditolak dan $\mathrm{H}_{3}$ diterima sehinggakepuasan kerja berpengaruh positif dan signifikan terhadap keinginan untuk keluar.

Hasil koefisien jalur pada hipotesis penelitian dapat digambarkan pada Gambar 1

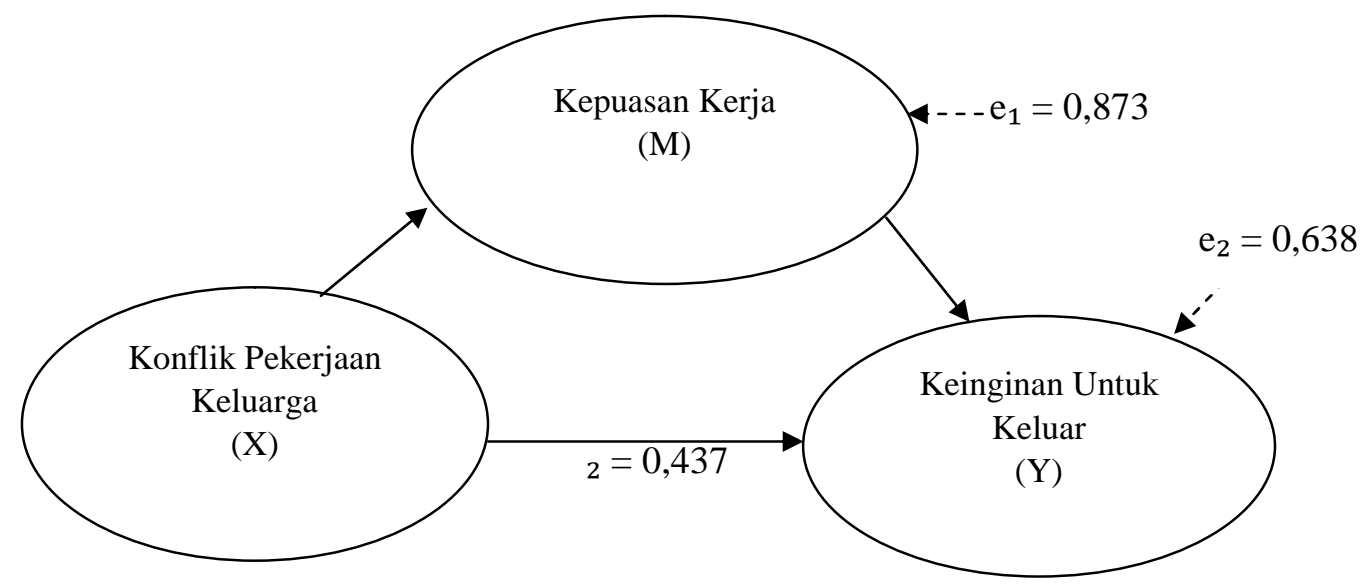

\section{Gambar 1.Model Diagram Jalur Akhir}


Berdasarkan model diagram jalur akhir pada Gambar 1, maka dapat dihitung besarnya pengaruh langsung, pengaruh tidak langsung, serta pengaruh total antar variabel. Perhitungan pengaruh antar variabel dirangkum dalam Tabel 4.

Tabel 4.

Pengaruh Langsung Dan Pengaruh Tidak Langsung serta Pengaruh Total Konflik Pekerjaan Keluarga (X), Kepuasan Kerja (M), dan Keinginan Untuk

$\operatorname{Keluar}(\mathbf{Y})$

\begin{tabular}{cccc}
\hline Pengaruh Variabel & $\begin{array}{c}\text { Pengaruh } \\
\text { Langsung }\end{array}$ & $\begin{array}{c}\text { Pengaruh Tidak Langsung } \\
\text { Melalui Kepuasan kerja } \\
\left(\boldsymbol{\beta}_{\mathbf{1}} \mathbf{x} \boldsymbol{\beta}_{\mathbf{3}}\right)\end{array}$ & Pengaruh Total \\
\hline $\mathrm{X} \rightarrow \mathrm{M}$ & $-0,322$ & - & -0.322 \\
$\mathrm{X} \rightarrow \mathrm{Y}$ & 0,437 & 0,142 & 0,373 \\
$\mathrm{M} \rightarrow \mathrm{Y}$ & $-0,441$ & - & $-0,441$ \\
\hline
\end{tabular}

Sumber: Data diolah, 2018

Berdasarkan Tabel 4 dapat dilihat bahwa konflik pekerjaan keluarga memiliki pengaruh langsung terhadap keinginan untuk keluar dan pengaruh tidak langsung melalui kepuasan kerja. Besarnya koefisien pengaruh tidak langsung dapat dihitung dengan mengalikan koefisien jalur dari konflik peran keluarga ke kepuasan kerja dengan koefisien jalur dari kepuasan kerja ke keinginan untuk keluar sebesar $-0,322 \times-0,441=0,142$. Hasil koefisien pengaruh tidak langsung lebih kecil dibandingkan pengaruh langsung $(0,142<0,437)$, sehingga dapat dikatakan bahwa variabel kepuasan kerja adalah sebagai variabel mediasi dalam memediasi pengaruh variabel konflik pekerjaan keluarga tehadap variabel keinginan untuk keluar.

Pengujian signifikansi dari hubungan tidak langsung antara variabel independen dengan variabel dependen yang dimediasi oleh variabel mediasi dapat menggunakan alat analisis yang disebut uji Sobel. Uji Sobel dirumuskan dengan persamaan berikut:

$\mathrm{Z}=\frac{\mathrm{ab}}{\sqrt{\mathrm{b}^{2} \mathrm{~S}_{\mathrm{z}}^{2}+\mathrm{a}^{2} \mathrm{Sb}^{2}+\mathrm{S}_{\mathrm{a}}^{2} \mathrm{Sb}^{2}}}$

Keterangan:

$\mathrm{S}_{\mathrm{a}} \quad=$ standar eror keofisien $\mathrm{a}$

$\mathrm{S}_{\mathrm{b}} \quad=$ standar eror keofisien $\mathrm{b}$ 


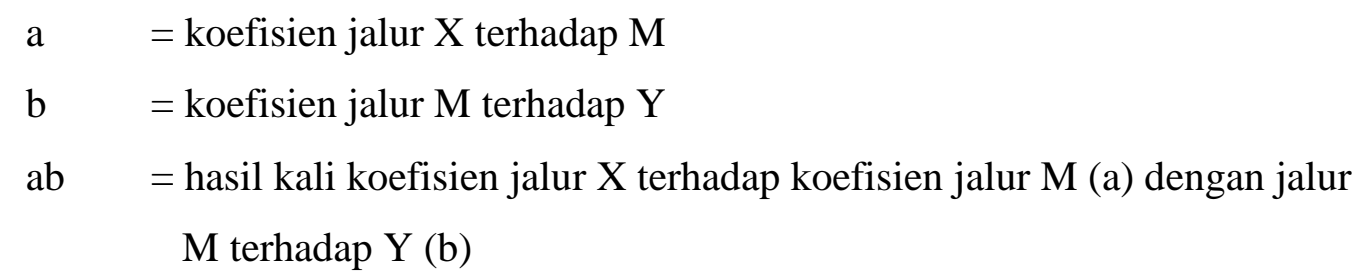

Setelah mendapatkan hasil z hitung, selanjutnya dibandingkan dengan nilai z tabel yaitu 1,96. Jika nilai z hitung lebih besar dari z tabel, maka kesimpulannya adalah terjadi pengaruh mediasi secara signifikan. Perhitungan Uji Sobel untuk pengaruh tidak langsung antara konflik pekerjaan keluarga terhadap keinginan untuk keluar melalui kepuasan kerja dihitung sebagai berikut:

$$
\begin{aligned}
& \mathrm{z}=\frac{\mathrm{ab}}{\sqrt{\mathrm{b}^{2} \mathrm{~S}_{2}{ }^{2}+\mathrm{a}^{2} \mathrm{Sb}^{2}+\mathrm{S}_{2}{ }^{2} \mathrm{Sb}^{2}}} \\
& \mathrm{z}=\frac{(-\mathrm{U}, 3 \mathrm{y} \mathrm{U}) \times(-0,388)}{\sqrt{(-0,388)^{2} \times 0,189^{2}+(-0,580)^{2} \times 0,110^{2}+0,189^{2} \times 0,110^{2}}} \\
& \mathrm{z}=\frac{0,22304}{\mathrm{U}, 0993 \mathrm{y}} \\
& \mathrm{z}=2,264
\end{aligned}
$$

Berdasarkan perhitungan, didapatkan nilai z hitung sebesar 2,264 yang artinya lebih besar dari nilai z tabel $(2,264>1,96)$. Hasil ini memiliki arti bahwa kepuasan kerja mampu memediasi pengaruh konflik pekerjaan keluarga terhadap keinginan untuk keluar. Oleh karena itu, $\mathrm{H}_{4}$ yang menyatakan bahwa kepuasan kerjamampu memediasi pengaruh konflik pekerjaan keluarga terhadap keinginan untuk keluar diterima.

Berdasarkan hasil pengujian hipotesis pertama, diperoleh nilai koefisien beta sebesar $-0,322$ dengansignifikansisebesar 0,024. Nilai koefisien beta yang 
memiliki arah negatif serta nilai signifikansi yang lebih kecil dari tingkat probabilitas 0,05 mengartikan bahwa $\mathrm{H}_{0}$ ditolak dan $\mathrm{H}_{1}$ diterima. Hasil dari pengujian ini adalah konflik pekerjaan keluarga berpengaruh negatif dan signifikan terhadap kepuasan kerja. Artinya, apabila konflik peran keluargarendah maka tingkat kepuasan kerja yang dimiliki para karyawan pada staff room division di The Jayakarta Hotel Bali akan semakin tinggi. Sebaliknya, jika konflik pekerjaan keluargatinggi maka kepuasan kerja para karyawan pada staff room division di The Jayakarta Hotel Bali akan semakinrendah.

Hasil penelitian ini sejalan dengan beberapa penelitian sebelumnya yang telah membuktikan bahwa konflik pekerjaan keluarga berpengaruh negatif dan signifikan terhadap kepuasan kerjaseperti yang dilakukanNetermeyer et al.(2004) yang menemukan bahwa pekerjaan yang tidak bisa menyeimbangkan antara kebutuhan pekerjaan dengan tanggung jawab keluarga dan rumah tangga serta mengalami benturan terhadap hal tersebut maka akan menghasilkan penurunan kepuasan kerja. Hasil yang sama juga diperoleh dari penelitian yang dilakukan Latifah (2008), Rantika dan Sunjoyo (2011), Laksmi (2012), serta Susanto (2010).

Berdasarkan hasil pengujian hipotesis kedua, diperoleh nilai koefisien beta sebesar 0,437 dengansignifikansisebesar 0,002. Nilai koefisien beta yang memiliki arah positif serta nilai signifikansi yang lebih kecil dari tingkat probabilitas 0,05 mengartikan bahwa $\mathrm{H}_{0}$ ditolak dan $\mathrm{H}_{2}$ diterima. Hasil dari pengujian ini adalah konflik pekerjaan keluarga berpengaruh positif dan signifikan terhadap keinginan untuk keluar. Artinya, apabila konflik pekerjaan keluargarendah maka keinginan para karyawan pada staff room division di The 
Jayakarta Hotel Bali untuk keluardari perusahaan akan semakin rendah. Sebaliknya, jika konflik pekerjaan keluargarendah maka keinginan para karyawan pada staff room division di The Jayakarta Hotel Baliuntuk keluardari perusahaan akan meningkat.

Hasil penelitian ini memperkuat beberapa penelitian sebelumnya yang telah membuktikan bahwa konflik pekerjaan keluarga berpengaruh positif dan signifikan terhadap keinginan untuk keluarseperti yang dilakukan Blomme et al. (2010) yang menemukan hasil konflik pekerjaan keluarga memiliki pengaruh positif terhadap keinginan untuk keluar. Begitu juga penelitian yang dilakukan Ghayyur dan Jamal (2012), Netmeyeret al. (1996), serta Raza-ullah et al.(2014).

Berdasarkan hasil pengujian hipotesis ketiga, diperoleh nilai koefisien beta sebesar -0,441 dengansignifikansisebesar 0,001. Nilai koefisien beta yang memiliki arah negatif serta nilai signifikansi yang lebih kecil dari tingkat probabilitas 0,05 mengartikan bahwa $\mathrm{H}_{0}$ ditolak dan $\mathrm{H}_{3}$ diterima. Hasil dari pengujian ini adalah kepuasan kerja berpengaruh negatif dan signifikan terhadap keinginan untuk keluar. Artinya, apabila tingkat kepuasan kerjatinggi maka keinginan para karyawan pada staff room division di The Jayakarta Hotel Bali untuk keluardari perusahaan akan semakin rendah. Sebaliknya, jika kepuasan kerja rendah maka keinginan para karyawan pada staff room division di The Jayakarta Hotel Bali untuk keluar dari perusahaan akan semakintinggi.

Hasil penelitian ini memperkuat beberapa penelitian sebelumnya yang telah membuktikan bahwa kepuasan kerja berpengaruh negatif dan signifikan terhadap keinginan untuk keluarseperti penelitian yang dilakukan Aydogdu dan Asikgil 
(2011) yang membuktikan bahwa jika karyawan tidak puas dengan pekerjaanpekerjaan mereka, karyawan akan meninggalkan organisasi tersebut, begitupun sebaliknya jika karyawan percaya bahwa mereka diperlakukan secara adil dan mendapatkan penghargaan mereka tidak mungkin meninggalkan organisasi. Hasil yang sama juga diperoleh Sallehet al.(2012), Andani (2013), McClean dan andrew (2000), serta Park dan Kim (2009).

Berdasarkan hasil pengujian hipotesis keempat, diperolehhasil pengaruh tidak langsung konflik pekerjaan keluarga terhadap keinginan untuk keluar melalui mediasi kepuasan kerjadengan koefisien yang lebih kecil dibandingkan pengaruh langsung yaitu $0,142<0,437$. Sementara itu, pengujian dengan uji Sobel menunjukkan bahwa nilai z hitung sebesar 2,264 yang lebih besar dari z tabel yaitu 1,96 sehingga $\mathrm{H}_{4}$ diterima. Hasil ini mengartikan bahwa kepuasan kerja mampu memediasi pengaruh konflik pekerjaan keluarga terhadap keinginan untuk keluar. Oleh karena itu, dapat diinterpretasikan bahwa konflik pekerjaan keluarga para karyawan pada staff room division di The Jayakarta Hotel Baliyang rendah akan berdampak pada tingginya kepuasan kerja yang dirasakan karyawan sehingga keinginan para karyawan pada staff room division di The Jayakarta Hotel Baliuntuk keluar dari perusahaan akan semakin rendah. Hasil penelitian ini sesuai dengan penelitian sebelumnya yang dilakukan oleh Irzani (2014) yang memperoleh hasil bahwa kepuasan kerja memediasi secara parsial negatif dengan keinginan keluar karyawan.

Implikasi penelitian ini menekankan pada manfaat nyata dari hasil penelitian yang telah dilakukan. Penelitian ini menggunakan pendekatan konflik 
pekerjaan keluarga dan kepuasan kerja yang merupakan pengaruh langsung dari keinginan untuk keluar dari perusahaan. Konflik pekerjaan keluarga terbukti secara negatif mempengaruhi kepuasan kerja, berdasarkan hasil pengujian hipotesis pertama, diperoleh nilai koefisien beta sebesar $-0,322$ dengansignifikansisebesar 0,024. Nilai koefisien beta yang memiliki arah negatif serta nilai signifikansi yang lebih kecil dari tingkat probabilitas 0,05 mengartikan bahwa $\mathrm{H}_{0}$ ditolak dan $\mathrm{H}_{1}$ diterima,Hasil dari pengujian ini adalah konflik pekerjaan keluarga berpengaruh negatif dan signifikan terhadap kepuasan kerja. Oleh karena itu penting bagi manajemen The Jayakarta Hotel Bali untuk selalu memperhatikan faktor-faktor yang menyebabkan konflik pekerjaan keluarga karyawan sehingga dapat mencegah adanya tekanan peran yang muncul dari tempat kerja dan mempengaruhi lingkup keluarga yang saling bertentangan. Konflik pekerjaan keluarga yang memiliki arah positif terhadap keinginan keluar, berdasarkan hasil pengujian hipotesis kedua, diperoleh nilai koefisien beta sebesar 0,437 dengansignifikansisebesar 0,002 . Nilai koefisien beta yang memiliki arah positif serta nilai signifikansi yang lebih kecil dari tingkat probabilitas 0,05 mengartikan bahwa $\mathrm{H}_{0}$ ditolak dan $\mathrm{H}_{2}$ diterima. Hasil dari pengujian ini adalah konflik pekerjaan keluarga berpengaruh positif dan signifikan terhadap keinginan untuk keluar, ini juga semestinya menjadi perhatian manajemen The Jayakarta Hotel Bali untuk memperhatikan hal-hal yang berdampak pada konflik pekerjaan keluarga agar karyawan pada staff room division tidak memiliki keinginan atau niat untuk mencari suatu pekerjaan lain sebagai alternatif di perusahaan yang berbeda. 
Kepuasan kerja terbukti secara negatif mempengaruhikeinginan untuk keluar,Berdasarkan hasil pengujian hipotesis ketiga, diperoleh nilai koefisien beta sebesar -0,441 dengansignifikansisebesar 0,001. Nilai koefisien beta yang memiliki arah negatif serta nilai signifikansi yang lebih kecil dari tingkat probabilitas 0,05 mengartikan bahwa $\mathrm{H}_{0}$ ditolak dan $\mathrm{H}_{3}$ diterima. Hasil dari pengujian ini adalah kepuasan kerja berpengaruh negatif dan signifikan terhadap keinginan untuk keluar. Oleh karena itu perhatian terhadap faktor-faktor yang mempengaruhi kepuasan kerja karyawan pada organisasi hendaknya ditingkatkan. Ketika karyawan pada staff room division di The Jayakarta Hotel Bali memiliki sikap yang positif terhadap pekerjaannya, maka kepuasan yang tinggi tersebut akan mempengaruhi rendahnya keinginan untuk keluar dari perusahaan. Minimnya tingkat keluarnya karyawan dari perusahaan dapat meminimalisir biaya organisasi yang berkaitan dengan rekrutmen, seleksi, serta pelatihan personil baru. Keterkaitan antara konflik pekerjaan keluarga, kepuasan kerja, dan keinginan untuk keluar bisa dijadikan pertimbangan bagi perusahaan lainnya dalam keputusan menyangkut sumber daya manusia demi terciptanya operasional perusahaan yang lebih baik.

\section{SIMPULAN DAN SARAN}

Berdasarkan pada hasil serta pembahasan penelitian yang telah dipaparkan, maka dapat disimpulkan bahwa konflik pekerjaan keluarga berpengaruh secara negatif dan signifikan terhadap kepuasan kerja. Hasil ini menunjukkan bahwa apabila konflik peran keluarga di tempat kerja rendah, maka tingkat kepuasan kerja yang dirasakan para karyawan pada staff room division di The Jayakarta 
Hotel Bali akan semakin tinggi. Sebaliknya, jika konflik pekerjaan keluarga tinggi maka kepuasan kerja para karyawan pada staff room division di The Jayakarta Hotel Bali akan semakin rendah.

Konflik pekerjaan keluarga berpengaruh secara positif dan signifikan terhadap keinginan untuk keluar. Hasil ini menunjukkan bahwa apabila konflik pekerjaan keluarga di tempat kerja rendah, maka keinginan para karyawan pada staff room division di The Jayakarta Hotel Bali untuk keluar dari perusahaan akan semakin rendah. Sebaliknya, jika konflik pekerjaan keluarga tinggi maka keinginan para karyawan pada staff room division di The Jayakarta Hotel Bali untuk keluar dari perusahaan akan meningkat.

Kepuasan kerja berpengaruh secara negatif dan signifikan terhadap keinginan untuk keluar. Hasil ini menunjukkan bahwa apabila tingkat kepuasan kerja tinggi maka keinginan para karyawan pada staff room division di The Jayakarta Hotel Bali untuk keluar dari perusahaan akan semakin rendah. Sebaliknya, jika kepuasan kerja rendah maka keinginan para karyawan pada staff room division di The Jayakarta Hotel Bali untuk keluar dari perusahaan akan semakin tinggi.

Kepuasan kerja mampu memediasi pengaruh konflik pekerjaan keluarga terhadap keinginan untuk keluar. Hasil ini menunjukkan bahwa konflik pekerjaan keluarga para karyawan pada staff room division di The Jayakarta Hotel Bali yang rendah di tempat kerja akan berdampak pada tingginya kepuasan kerja yang dirasakan karyawan sehingga keinginan para karyawan untuk keluar atau meninggalkan perusahaan akan semakin rendah. 
Berdasarkan hasil analisis, pembahasan, dan simpulan, maka saran yang dapat diberikan adalah manajemen departemen personalia TheJayakarta Hotel Bali hendaknya selalu memperhatikan faktor-faktor yang menyebabkan konflik pekerjaan keluarga karyawan di tempat kerja agar tidak menimbulkan kesulitan pemenuhan pekerjaan dalam keluarga dan kesulitan pemenuhan pekerjaan dalam pekerjaan. Hal tersebut demi meningkatkan kepuasan kerja karyawan dan membuat keinginan para karyawan pada staff room division di The Jayakarta Hotel Bali untuk keluar dari perusahaan yang disebabkan konflik pekerjaan keluarga dapat lebih rendah.

Peningkatan perhatian pada faktor-faktor yang mempengaruhi kepuasan kerja seperti kenaikan gaji, pekerjaan itu sendiri, peningkatan terhadap jabatan karyawan menjadi penting karena ketika para karyawan pada staff room division di The Jayakarta Hotel Bali merasakan kepuasan yang tinggi terhadap factor kepuasan dalam bekerja, maka mereka akan merasa senang dan nyaman dengan kondisi lingkungan perusahaan serta mendapatkan penghargaan dari jerih payah hasil kerjanya sehingga keinginan untuk keluar dari perusahaan akan semakin rendah.

Sebaiknya manajer hotel juga memperhatikan gaji atau reward karyawan yang bekerja melebihi jam kerja atau shift pada umumnya. Agar tidak terjadi ketimpangan antara jam kerja yang bertambah dengan hak yang seharusnya di dapatkan karena itu dapat menurunkan semangat dalam bekerja.

\section{REFERENSI}

Amstad,F.T.,Meier,L.L.,Fasel,U., Elfering.A, and Semmer,N.K. (2011). A metaanalysis of work family conflict and various and outcomes with a special 
emphasis on cross-domain versus matching domain relation. Journal of occipational health psychology, 16(1), Pp. 151-169.

Andini,Rita.(2013). Analisis Pengaruh Kepuasan Gaji, Kepuasan Kerja, Komitmen Organisasi terhadap Turnover Intention. Thesis.Program Studi Magister Management, Program Pasca Sarjana, Universitas Diponegoro, Semarang

Apperson, M., Schimdt, H.,Moore,S., and Grunberg, L. (2002). Women Managers and The Experience of Work-Family Conflict. American Journal of Undergraduate Research, 1(3), Pp. 9-16.

Aydogdu, Sinem and Asikgil Baris. (2011). An Empirical Study of The Relations hip Among Job Satisfaction, Organizational Commitment and Turnover Intention. International Review of Management and Marketing, 1(3), Pp. 43-53.

Aziri, B. (2011). Job Satisfaction: A Literature Review. Management Research and Practice. 3,(4), Pp. 77-86

Blomme, R. J.,Rheed, A. V., and Tromp, D. M. (2010). Work-Family Conflict as A Cause for Turnover Intentions in The Hospitality Industry. Tourism and Hospitality Research, 10(4), Pp. 269-285.

Ghayyur, Muhammad and Jamal Waseef. (2012). Work family conflict : A case of Employees turnover intention. Journal of social science and humanity.1(1), Pp. 145-157.

Greenhaus,J.H.,Beutell,N.J.(1985). Source of Conflict between Work and Family Roles. Academy of Management Review. 31(1), Pp. 72-92.

Irzani, Dwi., Andre Dwijanto Witjaksono. (2014). Pengaruh konflik peran dan ambiguitas peran terhadap keinginan keluar karyawan dengan kepuasan kerja sebagai variabel mediasi pada PT. Asuransi Raksa Pratikarsa di Surabaya. Jurnal Ilmu Manajemen. 2 (1), hal.10-25

Laksmi, Nimas Ayu Putri dan Coolchul Hadi.(2012).’Hubungan antara Konflik Peran Ganda (Work Family Conflict) dengan Kepuasan Kerja pada Karyawan bagian Produksi PT.X”. Jurnal Psikologi Industri dan Organisasi, 1(2), hal.72-80.

Latifah, Ifah (2008) Pengaruh Konflik Pekerjaan-Keluarga Terhadap Turnover Intentions Dengan Kepuasan Kerja Sebagai Variabel Intervening (Studi Empiris Pada Auditor Kantor Akuntan Publik Di Indonesia).Masters thesis, Diponegoro University.

McClean,L.,Andrew,T. (2000). Commitment, Satisfaction, Stress and Control Among Social Service Managers and Social Workers in the Uk.In: Administration in Social Work, 23(34), Pp. 93-117. 
Netemeyer, R.G., Boles, J.S., dan McMurrian, R. (1996). Development and validation of work-family conflict and family-work scales. Journal of Applied Psychology. 81(4), Pp. 400-410.

Netermeyer,R.G., Brashear Alenjandro,T., Boles,J.S. (2004). A crossnational Model Of Job-related Outcome of Work Role and Family Role variables:a retail sales context.In:Journal of the Academy of Marketing, Science, 32(1), Pp. 49-60.

Nohe, C., and Karlheinz, S. (2014). Work-Family Conflict, Social Support, and Turnover Intentions: A Longitudinal Study. Journal of Vacational Behavior, $\quad 85$ (1), Pp. 1-12.

Park Jae San dan Kim Tae Hyun. (2009). Do Types of Organizational Culture Matter in Nurse Job Satisfication and Turnover Intention. Leadership in Health Service, 22(1), Pp. 20-38.

Primastuti, E. (2000). Peran Ganda Wanita Dalam Keluarga. Dalam Seri Kajian Ilmiah,10(1), hal 54-63.

Rantika, Renny dan Sunjoyo. (2011). Pengaruh konflik kerja keluarga terhadap komitmen organisasi yang dimediasi oleh kepuasan kerja pada profesi perawat di Rumah Sakit Umum Daerah (RSUD) DR.Moewardi Surakarta. Jurnal Manajemen Teori dan Terapan, 2(4), hal. 28-43.

Raza-ullah Khan, Muhammad., Nabila Nazir., Sarwat Kazmi., Ayesha Khalid., Talat Mahmood Kiyani dan Asif Shahzad. (2014). Work Family Conflict and Turnover Intention: Mediating Effect of Stress. Internasional Journal of Humanities and Social Science. 4(5), Pp. 92-100.

Rini, Dyah P., Rusdarti, Suparjo. (2013). Pengaruh Komitmen Organisasi, Kepuasan Kerja, dan Budaya Organisasi terhadap Organizational Citizenship Behavior (OCB) (Studi pada PT, Plasa Simpanglima Semarang). Jurnal Ilmiah Dinamika Ekonomi dan Bisnis. 1(1), hal. 22372248.

Rini,J,F. (2002). Stres Kerja. http://www.e-psikologi.com/masalah/stres.htm (1 Februari (2015)).

Salleh, R., Mishaliny S.N and Haryani H. (2012). Job Satifaction, Organizational Commitment and Turnover Intention : A Care Study on Employees of a Retail Company in Malaysia. Work Academy of Science, Enginering and Technology. 2(4), Pp: 316-328.

Susanto. (2010). Analisis Pengaruh Konflik Kerja-Keluarga terhadap Kepuasan Kerja Pengusaha Wanita di Kota Semarang. Aset.12(1), hal. 75-85. 
Tett, RT and Meyer J.P., (1993). Job Satisfication, Organizational Commitment, Turnover Intentionand Turnover. Personnel Psychology.46(2) Pp. 153167.

Turkmilyaz, Ali, Akman Gulsen, Ozkan Coskun \& Pastuak Zbigniew. (2011). Empirical Study of Public Sector Employee Loyalty and Satisfaction. Industrial Management \& Data Systems. 111(5), Pp. 675-696

Waspodo, Agung AWS., Nurul Chotimah Handayani dan Widya Paramita. (2013). Pengaruh Kepuasan Kerja dan Stres Kerja terhadap Turnover Intention pada Karyawan PT. Unitex di Bogor. Jurnal Riset Manajemen Sains Indonesia (JRMSI). 4(1), hal. 270-294.

Widyaningrum, A.I. Pongtuluran. Y,.dan Tricahyadinata.I. (2013). Pengaruh Konflik Peran Ganda dan Stress Kerja Terhadap Kinerja Karyawan Wanita Pada Swalayan Era Mart 5000 Di Samarinda. Jurnal Fakultas Ekonomi Mulawarman. 1(1), hal. 115-130.

Yuliana, Evy Siska dan Reny Yuniasanti. (2013). Hubungan Antara Konflik Pekerjaan-Keluarga dengan Kepuasan Kerja pada Polisi Wanita di POLRES Kulon Progo. Jurnal Sosio Humaniora. 4(5), Pp. 62-73. 